\title{
Crimes in the name of research
}

\author{
Das Robert Koch-Institut im \\ Nationalsozialismus \\ by Annette Hinz-Wessels \\ Kulturverlag Kadmos: 2008. 192 pp. \\ $€ 22.50$ (in German)
}

The Robert Koch Institute in Berlin was founded in 1891 and conducts research into infectious bacteria and viruses. When it celebrated its centenary, the crimes committed by members of the institute between 1933 and 1945 were apparently not of interest, and were not mentioned. Ten years later, after the Max Planck Society and the DFG, Germany's main research-funding agency, had investigated their own histories, this changed. Scientist Annette Hinz-Wessels has written the first history of the institute, concentrating on the years under National Socialism.

Das Robert Koch-Institut im Nationalsozialismus (The Robert Koch Institute Under National Socialism) begins by presenting the history of the institute from 1891 to 1933. When the Nazis took power in 1933, it had one director and six group leaders, all non-Jewish, and the reigning powers saw no need to fire any of them. But they were all of retirement age, so the intellectual power of the institute was reconstructed after 1933 according to the wishes of the Nazis.

Twelve research scientists, including postdocs and technicians, were fired because they were Jewish. Any reader would like to know what happened to these people during and after the Nazi era, yet the book says little about their fate. Was there an attempt to hire them again? One of them who survived in Berlin was invited back, but there is no further mention of the others.

Three of the institute scientists discussed in the book - Claus Schilling, Gerhard Rose and Eugen Haagen - have been analysed previously. Schilling was one of the group leaders who retired. He had once been a state medical doctor in Togo, west Africa, where he became fascinated by malaria. After his retirement, he continued to try to construct a vaccine for the disease, and between 1942 and 1945, he used prisoners from the concentration camp at Dachau in southern Germany for his malaria experiments. Of the

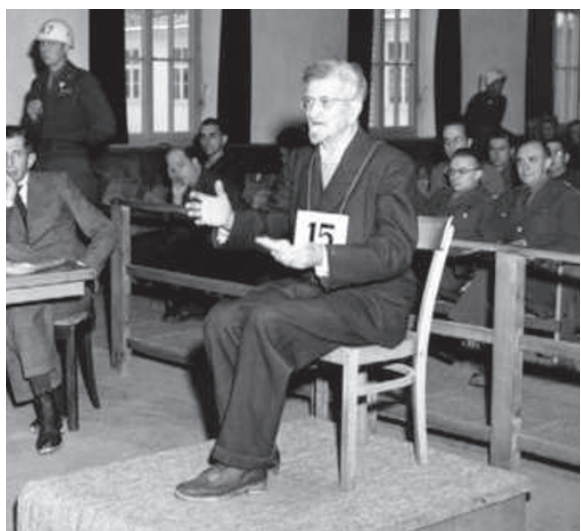

Despite facing a death sentence, Schilling asked to publish the results of his unethical malaria studies.

1,200 people he infected with malaria, between 300 and 400 died. Schilling was caught by the Allies and executed in 1946.

Schilling's successor as group leader was Rose, who had worked in China and was interested in typhus. He too used prisoners from concentration camps and killed many people in his experiments. He was condemned to life imprisonment at the Nuremberg trials after the Second World War, but was released in 1955. According to journalist Ernst Klee, who exposed many medical crimes of the Nazis in his book Das Personenlexicon zum Dritten Reich (Fischer; 2003), Rose became a member of the Max Planck Society in 1962.

Hinz-Wessels also discusses Haagen, who was a virologist. He was condemned to a jail sentence by a French court for his murderous experiments in a concentration camp in Alsace, in what is now eastern France. Released after a short time, he joined a virus laboratory in Tübingen, Germany, and received grant support from the DFG in 1957. Hinz-Wessels quotes from a letter Haagen wrote in August 1943 to Rose, which reads: "I contacted the central office of the SS [the Nazi protective squadron] to receive sufficient human material from worthless lives for our purpose". Schilling, Rose and Haagen are the worst scientists described and, although their experiments were already broadly known, this book adds new detail.

The book is well written and accurate. Some material might have been better presented in tables, such as the names of people fired from the institute in 1933, the names of the group leaders and those who were murdered. Published in German, it will be of interest to those now working in the Robert Koch Institute or at similar institutions. An English translation is warranted and will attract readers.

What is the bottom line? Do not try to write the history of bad scientists when any of them are still alive. Like Hinz-Wessels, do it only when all of those who were involved are dead

Benno Müller-Hill is emeritus professor of genetics at the University of Cologne, 50674 Cologne, Germany. He is the author of Murderous Science. e-mail: muellerhill@uni-koeln.de

\section{Conspiracy at the bench}

Experimental Heart: A Novel

by Jennifer L. Rohn

Cold Spring Harbor Laboratory Press: 2008.

364 pp. \$13.99, £7.99

The scene in The Day of the Jackal, in which the lone assassin carefully assembles his rifle, each step and component carefully described, is one of the most memorable in literature. Such detail tells us that the author, former serviceman and war correspondent Frederick Forsyth, really knew his stuff. More importantly, it increases the tension to an almost unbearable pitch, just before the climax when the assassin will take a shot at his target. Here is another climax:

"The answer clicked into place with an almost physical impact. Gina had inadvertently inserted the wrong gene into her herpes virus vectors, having been led to believe that it was in fact FRIP. Clearly, Rouyle had never had any intention of using FRIP in combination with her gene therapy vectors at all.

I slammed my fist onto the opened notebook. The conclusion was inescapable. And there were now two key questions remaining. One, what was the mystery gene that had been swapped in FRIP's place? And, two, was this substitution a secret only of Rouyle's, or was Pfeiffer-DeVries in on it as well? Or even Boyd? My mind reeled at the possible layers of conspiracy."

This scene, told by a lone researcher in his laboratory, late at night, is from cell biologist Jennifer Rohn's first novel, Experimental Heart. It takes place in a cancer-research centre in London, in which a biotech company called Geniaxis has inveigled itself like a tumour. Cell-cyclist Andy O'Hara, a postdoc who has hitherto sublimated all romantic instincts into work, sees Geniaxis virologist Gina Keyser through her lit lab window late one night, and is smitten. O'Hara, ensnared, becomes involved in Keyser's work and sinks into a quagmire of intrigue, only to be resolved when he is forced to carry out some risky detective work.

At the heart of the story, which Rohn tells well for the most part, is a mystery that turns 